\title{
PARTISIPASI ORANG TUA TERHADAP PELAKSANAAN PROGRAM PAUD DI SPS CAHAYA HATI
}

\author{
Ela Nurhasnah \\ IKIP Siliwangi \\ elanurhasanah1985@gmail.com
}

\begin{abstract}
ABSTRAK
Penelitian ini bertujuan untuk mendeskripsikan: (1) partisipasi orang tua terhadap pelaksanaan program PAUD, (2) faktor pendukung dan faktor penghambat partisipasi orang tua terhadap pelaksanaan program PAUD di SPS Cahaya Hati". Penelitian ini menggunakan pendekatan kualitatif, dan mengambil lokasi penelitian di "SPS Cahaya Hati”. Subyek penelitian ini adalah orangtua anak didik. Pengumpulan data dilakukan dengan menggunakan metode wawancara, observasi, dan dokumentasi. Peneliti merupakan instrumen utama dalam melakukan penelitian yang dibantu oleh pedoman wawancara, pedoman observasi, dan pedoman dokumentasi. Teknik yang digunakan dalam analisis data adalah reduksi data, menampilkan data, dan verifikasi data. Trianggulasi yang dilakukan untuk menjelaskan keabsahan data dengan menggunakan sumber. Hasil penelitian menunjukkan bahwa partisipasi orang tua, meliputi: bentuk partisipasi orang tua yaitu memberikan sumbangan tenaga fisik, sumbangan finansial, sumbangan material, sumbangan material, sumbangan moral, dan sumbangan dalam mengambil keputusan; keterlibatan orang tua, hasil partisipasi yaitu seluruh kegiatan yang diselenggarakan oleh lembaga berjalan lancer; dan dampak hasil partisipasi yaitu pelaksanaan program PAUD lancar; 2) faktor pendukung berasal dari penyelenggara PAUD yang memberikan pelayanan pendidikan bagi ibu, struktur organsisasi yang tertata rapi, pendidik dan pengelola memahami arti pentingnya keterlibatan orang tua dalam program pendidikan anak usia dini, kepercayaan masyarakat terhadap lembaga dan ikut serta orang tua membantu lembaga dalam hal materiil maupun non materiil. Faktor penghambat yaitu masih adanya orang tua yang menunggu anaknya di dalam kelas, orang tua yang sibuk bekerja sehingga tidak bisa mengikuti pendidikan ibu dan adanya orang tua yang menyerahkan stimulasi perkembangan anaknya pada lembaga PAUD.
\end{abstract}

Kata kunci : meningkatkan partisipasi orang tua, terhadap pelaksanaa program paud

\section{A. PENDAHULUAN}

Secara umum, sebagaimana disebutkan dalam pasal 54 Undang-undang SISDIKNAS No. 20 Tahun 2003, keberhasilan pendidikan sangat bergantung pada peran serta masyarakat secara keseluruhan. Keluarga yang lebih spesifik adalah orang tua juga 
diharapkan perannya dalam penyelenggaraan pendidikan, baik sebagai sumber maupun pelaksana yang secara langsung maupun tidak menopang proses pendidikan. Menurut Ahmad D. Marimba pendidikan adalah bimbingan atau pimpinan secara sadar oleh pendidik terhadap perkembangan jasmani dan rohani terdidik menuju terbentuknya kepribadian yang utama.

Dilihat dari segi pemerataan kesempatan memperoleh pendidikan di Indonesia baik melalui jalur pendidikan sekolah maupun pendidikan luar sekolah menunjukkan bahwa anak usia dini yang memperoleh pelayanan pendidikan prasekolah masih sangat rendah. pada tahun 2002 dari sekitar 26.172.763 anak usia 0-6 tahun di Indonesia yang mendapatkan layanan pendidikan dari berbagai program PAUD yang ada baru sekitar 7.343.240 anak atau sekitar 28\%. Adapun untuk usia prasekolah yaitu usia 4-6 tahun masih terdapat sekitar10,2 juta $(83,8 \%) 5$ yang belum terlayani di pendidikan prasekolah. Dari keseluruhan jumlah anak usia 0-6 tahun yang mendapat layanan, jumlah terbesar berada di SD kelas awal yaitu 2.641 .262 anak (10\%) berikutnya melalui program Bina Keluarga Balita sebesar 2.526.205 anak (9,6\%), TK. sebesar 1.749 .722 anak (6,7\%), RA sebesar 378.094 anak (1,4\%). Kelompok bermain sebesar 36.649 anak $(0,1 \%)$, dan melalui TPA sebesar 15.308 anak (0,06\%). Dari keterangan tersebut dapat disimpulkan bahwa anak usia dini yang belum terlayani pendidikan anak usia dini sebesar 19,01 juta anak (72,64\%) (Fasli Jalal, 2004: 8). Orang tua selama ini hanya memasukkan anaknya ke pendidikan prasekolah dan menyerahkan sepenuhnya pendidikan anak pada lembaga. Tidak ada bentuk partisipasi orang tua dalam pendidikan anak usia dini. Sehingga perkembangan anak usia dini kurang optimal. Bentuk keterlibatan masyarakat dalam program PAUD ada dua yaitu bertidak pasif dan bertindak aktif. Bertindak aktif yaitu mendukung, mengajak orang lain untuk memperluas jangkauan dan mengembangkan serta meningkatkan hasil Kerangka Pemikiran Pengelolaan pendidikan anak usia dini menjadi salah satu prioritas pendidikan dasar.

\section{B. LANDASAN TEORI}

Pengertian Pendidikan Anak Usia Dini Undang-undang No. 20 Tahun 2003 tentang SISDIKNAS menyebutkan bahwa pendidikan adalah "usaha sadar dan terencana untuk mewujudkan suasana belajar dan proses pembelajaran agar peserta didik secara aktif mengembangkan potensi dirinya untuk memiliki kekuatan spiritual keagamaan, pengendalian diri, kepribadian, kecerdasan, akhlak mulia, serta ketrampilan yang diperlukan dirinya, masyarakat, bangsa dan Negara" (pasal 1, butir 1). Di dalam Undang-undang No. 20 tentang Sistem Pendidikan Nasional Tahun 2003 disebutkan mengenain pengertian PAUD yaitu: "Pendidikan Anak Usia Dini adalah suatu upaya pembinaan yang ditujukan kepada anak sejak lahir sampai dengan usia enam tahun yang dilakukan melalui pemberian rangsangan pendidikan untuk membantu pertumbuhan dan perkembangan jasmani dan rohani agar anak memiliki kesiapan dalam memasuki pendidikan lebih lanjut."

Program Layanan Pendidikan Anak Usia Dini

1) Bentuk Program Pendidikan Anak Usia Dini Jalur Formal 
a) Taman Kanak-kanak Taman Kanak-kanak adalah salah satu bentuk satuan pendidikan anak usia dini pada jalur pendidikan formal yang menyelenggarakan program pendidikan bagi anak usia empat tahun sampai enam tahun.

b) Raudhatul Athfal (RA), Bustanul Athfal (BA) Adalah salah satu bentuk satuan pendidikan anak usia dini pda jalur pendidikan formal yang menyelenggarakan program pendidikan umum dan pendidikan keagamaan Islam bagi anak berusia empat tahun sampai enam tahun. TK, RA, BA, untuk selanjutnya merupakan pendidikan anak usia dini dan di dalamnya terdapat Garis-garis Besar Program Kegiatan 12 Belajar (GBPKB), yakni usaha untuk mengetahui secara mendalam tentang perangkat kegiatan yang direncanakan untuk dilaksanakan dalam kurun waktu tertentu dalam rangka meletakkan dasar-dasar bagi pengembangan diri anak usia TK.

1) Bentuk Program Pendidikan Anak Usia Dini Jalur Non formal a) Taman Penitipan Anak Taman Penitipan Anak atau Day Care adalah sarana pengasuhan anak dalam kelompok, biasanya dilaksanakan pada saat jam kerja. Day Care merupakan upaya yang terorganisasi untuk mengasuh anak-anak di luar rumah mereka selama beberapa jam dalam satu hari bilamana asuhan orang tua kurang dapat dilaksanakan secara lengkap (Soemiatri Patmonodewo, 2000:43). Jadi TPA adalah lembaga sosial yang memberikan pelayanan kepada anak-anak bayi di bawah usia lima tahun (balita) yang dikhawatirkan akan mengalami hambatan dalam pertumbuhannya, karena ditinggalkan orang tua tau ibunya bekerja. Pelayanan ini diberikan dalam bentuk peningkatan gizi, intelektual, emosional dn sosial.

2) Anak lebih memiliki kesempatan berinteraksi atau berhubungan dengan teman sebaya yang akan membantu perkembangan kerja sama dan ketrampilan berbahasa. Anak dihadapkan pada kondisi proses sosialisasi yang alami. Dimana anak mulai mengenal teman yang satu dengan yang lain. Sehingga anak terbiasa dengan 15 lingkungan di luar rumah. Bahwa anak pun dituntut untuk bisa berinteraksi atau bersosialisasi dengan anak lain. Hal tersebut untuk membentuk jiwa sosial anak sejak dini.

3) Para orang tuanya mempunyai kesempatan saling berinteraksi dengan staf

4) TPA yang memungkinkan terjadinya peningkatan ketrampilan, pengetahuan dan tata cara pengasuhan anak. Kurangnya pengetahuan orang tua dalam cara mendidik maupun mengasuh anak akan berdampak buruk bagi perkembangan anak itu sendiri. Pola pengasuhan anak harus sesuai dan dilandasi oleh pengetahuan yang cukup. Oleh sebab itu pihak orang tua harus berusaha untuk sebanyak-banyaknya mendapatkan pengetahuan tentang mendidik anak yang baik dari TPA tersebut. Karena pada dasarnya pendidikan dan pengasuhan anak lebih banyak dalam lingkungan keluarga.

5) Anak akan mendapat pengawasan dari pengasuh yang bertugas. Terdapat tujuan khusus yang akan dicapai oleh TPA dalam mengasuh anak. Mereka memberikan stimulasi yang khusus ntuk mengoptimalkan kecerdasan anak. Sehingga orang tua tidak perlu khawatir menyerahkan pola pengasuhan dan pendidikan anaknya di TPA.

6) Tersedianya beragam peralatan rumah tangga, alat permainan program pendidikan, pengasuhan, serta kegiatan yang terencana. 
7) Tersedianya komponen pendidikan seperti anak belajar mandiri, berteman dan mendapat kesempatan mempelajari berbagai ketrampilan.

Bertujuan dalam rangka untuk menyiapkan anak-anak didiknya menjadi generasi Qurani, yaitu komitmen dan menjadikan al-Quran sebagai pandangan hidup sehari-hari. Anak dapat membaca al-Qur'an dengan benar sesuai dengan ilmu tajwid, dapat melakukan shalat dengan baik dan terbiasa hidup dalam suasana yang Islami, dapat menulis huruf-huruf al-Qur'an, hafal surat-surat pendek, ayat-ayat pilihan dan doa sehari-hari. Kemampuan membaca al-Qur'an dengan baik dan benar merupakan target dan sekaligus merupakan tujuan pokok dan perdana yang harus dicapai dan sekaligus dimiliki oleh setiap peserta santri. Taman pendidikan al-Qur'an berfungsi sebagai lembaga nonformal agar tidak terjadi kemerosotan agama dan generasi Qur'ani.

\section{METODE PENELITIAN}

Pemilihan metode yang tepat dalam penelitian ilmiah merupakan keharusan, maksudnya agar masalah yang diteliti dengan mudah dapat dicari jawabannya. Dalam penelitian ini peneliti engggunakan metode deskriptif dengan pendekatan kualitatif. Menurut Zuldafrial (2011: 3) penelitian kualitatif adalah penelitian yang berdasarkan data deskriptif berupa kata-kata tertulis atau lisan dari orang atau perilaku yang diamati, dalam mengumpulkan datanya sangat tergantung pada proses pengamatan yang dilakukan oleh peneliti itu sendiri dan temuannya tidak diperoleh melalui prosedur statistik dan bentuk hitungan lainnya.

Dalam menjawab pertanyaan riset atau masalah penelitian, metode deskriptif adalah yang paling sesuai digunakan karena metode ini menggambarkan dan menafsirkan kondisi, proses yang sedang berlangsung dan trend yang sedang berkembang.

\section{HASIL PENELITIAN DAN PEMBAHASAN}

Di samping itu, suasana mendukung karena berada di lingkungan SKB Bantul. SKB Bantul telah dikenal oleh masyarakat yangt membutuhkan ketrampilan untuk meningkatkan kesejahteraan hidup. Selain itu, SKB Bantul juga memberikan layanan pendidikan bagi masyarakat yang belum terlayani di pendidikan formal, sehingga sesuai untuk kegiatan belajar/pendidikan.

\section{Latar Belakang Pendirian}

Latar belakang berdirinya "SPS Cahaya Hati ini adalah berdasarkan masih kurangnya program pendidikan di wilayah perkampungan khususnya di lingkungan Kp. Kubang Desa Sukaresmi Kecamatan Rongga Kabupaten Banndung Barat. Hal ini disebabkan selain pendidik bertanggung jawab terhadap pendidikan anak usia dini di sekolah, tetapi pihak orang tua pun harus mempunyai pengetahuan tentang anak usia dini itu sendiri. Sehingga untuk membentuk kepribadian anak yang bermoral dan mengoptimalkan perkembangan anak, maka pendidikan ibu sangat dibutuhkan untuk stimulasi perkembangan anak yang tepat.

Visinya yaitu mengantar anak meraih masa depan sedangkan misinya yaitu pembelajaran, pembimbingan dan pelatihan. 
Tujuan:

a. Meningkatkan pengetahuan dan ketrampilan serta membina tumbuh kembang anak

b. Membantu meletakkan dasar ke arah perkembangan sikap mental, pengetahuan, ketrampilan yang diperlukan oleh anak-anak sampai memasuki jenjang pendidikan selanjutnya

c. Membantu ibu dalam menghantarkan pada 6 aspek perkembangan anak yang harus dicapai secara maksimal

\section{Struktur Organisasi SPS Cahaya Hati}

Struktur adalah sebagai berikut :

Penanggungjawab : Hilman, S.Pd.i

Ketua Yayasan $\quad$ : Ahmad M. S.Pd

Sekretaris : Ela Nurh,S.Pd

Bendahara $\quad$ : Kiki Sopi, S.Pd

Koordinator : Uman

Berdasarkan susunan pengurus tersebut, SPS Cahaya Hati dikelola oleh orang-orang yang terdidik dan kompeten di bidang pendidikan.

\section{Data pendidik dan tenaga kependidikan}

3.1 Data pendidik dan tenaga kependidikan SPS Cahaya Hati

\begin{tabular}{llcl}
\hline No & \multicolumn{1}{c}{ NAMA } & PENDIDIKAN & \multicolumn{1}{c}{ JABATAN } \\
\hline 1. & Hilman & S1 & Penanggung Jawab \\
2. & Ahmad Muhsin & $\mathrm{S} 1$ & Ketua Yayasan \\
3. & Dede Sulaeman & $\mathrm{S} 1$ & Kepala PAUD \\
4. & Ela Nurhasanah & $\mathrm{S} 1$ & Sekretaris \\
5. & Kiki Sopiyati & $\mathrm{S} 1$ & Bendahara \\
6. & Cicih Kuraesin & $\mathrm{S} 1$ & Tutor \\
7. & Leni Maftuhah & $\mathrm{S} 1$ & Tutor \\
8. & Lilis & $\mathrm{S} 1$ & Tutor \\
9. & Sopiyah & $\mathrm{S} 1$ & Tutor \\
\hline
\end{tabular}




\section{a. Penanggungjawab/ penasehat}

Penanggungjawab bertugas membimbing dan mengarahkan seluruh unsur yang ada di dalam organisasi. Memantau serta mengendalikan seluruh aktivitas yang ada dalam kegiatan menyangkut seluruh proses dari perencanaan sampai tahap evaluasi seluruh kegiatan program PAUD.

b. Ketua Yayasan

Ketua Yayasan Bertugas Mengelola Sekolah dengan baik

c. Ketua

Ketua bertugas untuk mengkonsultasikan pelaksanaan program. Melaksanakan pengawasan kepada pengurus. Selain itu ketua mempunyai wewenang untuk mengadakan pembagian tugas kepada seluruh anggota. Menjabarkan seluruh biaya yang dibutuhkan bagi penyelenggaraan program PAUD. Memantau jalannya kegiatan program PAUD serta mengevaluasi hasil program kegiatan. Kemudian ketua juga mempunyai tugas dan tanggunb jawab untuk melaporkan semua kegiatan yang telah terselenggara kepada pihak atasan untuk dipertanggungjawabkan.

\section{d. Bendahara}

Bendahara bertugas untuk menerima dan mencatat semua dana yang diterima. Menyimpan semua dana yang ada untuk selanjutnya mengeluarkan dana dengan persetujuan ketua dan penanggungjawab program. Selain itu bendahara juga mempunyai tugas untuk membuat laporan keuangan yang ada. Sehingga ada keterbukaan tentang pengelolaan keuangan yang dapat dipertanggungjawabkan.

e. Sekretaris atau anggota

Sekretaris maupun anggota bertugas mencatat seluruh aktivitas kegiatan program, mencatat hasil-hasil pemantauan dan evaluasi serta mengadministrasikan. Melaksanakan notulen kegiatan rapat. Selain itu juga membuat laporan kegiatan.

f. Pendidik Secara umum tugas pendidik adalah membimbing anak dan menyiapkan lingkungan belajar bagi proses pembelajaran. Secara umum tugas pendidik adalah membuat Rencana Program Pembelajaran (RPP), melaksanakan kegiatan belajar mengajar, melaksanakan evaluasi belajar, serta membuat laporan yang terkait dengan kegiatan teknis edukatif. Kurikulum mencakup semua aspek perkembangan anak: moral dan nilai agama, fisik motorik, kognisi, bahasa, social emosional dan seni. Kurikulum disesuaikan dengan tingkat usia anak didik berdasarkan aspekaspek yang dikembangkan.

\section{Keadaan Fasilitas Belajar}

Fasilitas belajar sangat diperlukan agar proses belajar mengajar dapat berjalan dengan baik. Di Kelompok Bermain SPS Cahaya Hati sendiri, fasilitas belajar yang tersedia antara lain adalah 1 gedung berisi 3 ruang belajar, 1 taman bermain, meja peserta didik 
sebanyak 8 buah, kursi plastik kecil 30 buah untuk anak, papan tulis 2 buah, almari 2 buah, loker 3 buah, tikar 3 buah, 2 rak sepatu, 2 kamar mandi, meja dan kursi 3 set. Pada saat belajar, anak dibagi menjadi 3 yakni sentra persiapan, sentra balok dan sentra alam.

Anak belajar di dalam ruangan dengan RPP sesuai dengan ketentuan dalam sentra masing-masing.

\section{Pengelolaan Anggaran}

Dana yang diperoleh untuk penyelenggaraan kegiatan Kelompok Bermain yaitu dari Anggaran Pendapatan dan Belanja Daerah (APBD) senilai 8 juta per tahun penggunaan dana tersebut digunakan untuk sarana dan prasarana, ATK, honor penyelenggara dan 2 pendidik. Rincian penggunaan dana yaitu Rp 4.800.000,- dipergunakan sebagai uang lelah 2 pendidik, Rp 1.800.000,- untuk 3 orang penyelenggara, bahan belajar sejumlah Rp 1.150.000,- dan Rp 250.000,- sisanya untuk pembelian ATK dan lain-lain. Selain dari APBD, dana yang diperoleh untuk penyelenggaraan diperoleh dari iuran per-bulan anak sebanyak Rp 25.000,- yang dianggap tidak memberatkan para orang tua.

Dana tersebut dipergunakan untuk biaya operasional pendidik, biaya operasional tenaga kependidikan, sarana dan prasarana, pengembangan pendidikan, pengembangan tenaga kependidikan, biaya pengembangan sarana dan prasarana. Honor pelatih renang, transpor pendidik serta acara pelepasan dan gebyar termasuk dalam penggunaan dana tersebut. Pengelolaan anggaran pendidikan yang terbuka akan mendorong masyarakat untuk berpartisipasi. Hal tersebut karena ada rincian penggunaan dana.

\section{Jadwal Kegiatan Belajar}

Jadwal pelaksanaan kegiatan ini adalah pada hari Senin-Sabtu. Senin-Rabu adalah kelas kelompok besar usia 4-5 tahun. Kamis-Sabtu kelas kelompok kecil usia 3-4 tahun. Kegiatan belajar anak dimulai pukul 08.00 sampai 10.00 WIB. Anak di ajak untuk berbaris di depan kelas untuk kegiatan senam. Kemudian anak masuk ke dalam ruang kelas sesuai dengan kelompoknya masing-masing. Sebelum memulai pembelajaan, pendidik menyapa anak, salam dan membaca do'a. Setelah itu, pendidik mengajak anak untuk berdiskusi yang berkaitan dengan tema dan memberikan kesempatan main untuk anak sesuai dengan minat mereka.

\section{Partisipasi Orang Tua terhadap Pelaksanaan Program PAUD}

Pentingnya partisipasi orang tua terhadap pelaksanaan program di Pentingnya partisipasi orang tua terhadap pelaksanaan program di SPS Cahaya Hati yaitu untuk keberhasilan dan kemajuan program PAUD. Orang tua merupakan faktor pendorong utama dalam keberhasilan program PAUD. Pengetahuan orang tua mengenai informasi bahwa pentingnya pendidikan di masa golden age merupakan salah satu bentuk partisipasi orang tua.

Tingkat kepercayaan para orang tua terhadap lembaga PAUD menjadi pintu utama bagi lembaga menuju keberhasilan program. Kepercayaan pada lembaga pendidikan tidak 
mudah diberikan untuk masyarakat. Sebagian besar kepercayaan masyarakat muncul karena dari pihak terdekat yaitu tetangga dan tokoh masyarakat itu sendiri mbak". Keberhasilan dari perencanaan pendidikan pada dasarnya tergantung pada tingkat kepedulian dan kesadaran masyarakat terhadap pendidikan itu sendiri. Oleh karena itu pihak lembaga dan tokoh masyarakat harus mampu menggerakkan tingkat kepedulian dan kesadaran masyarakat terhadap pendidikan bagi anak usia dini. Peran serta tokoh masyarakat dan berbagai komponen lainnya dalam pendidikan anak usia dini dan pendidikan masyarakat diharapkan dapat menopang dan mendukung pengembangan sistem pendidikan yang sesuai dengan kebutuhan masyarakat (Mulyono, 2018).

\section{Tujuan yang hendak dicapai partisipasi orang tua terhadap program di PAUD}

Tujuan yang hendak dicapai yaitu agar pelaksanaan program berjalan dengan lancar dan maju. Sehingga proses pendidikan bagi anak usia dini mencapai tujuannya yaitu mengoptimalkan kecerdasan anak sebagai investasi masa depan bangsa.

\section{Keterlibatan Orang Tua Dalam pelaksanaannya program}

Keterlibatan orang menjadi sangat penting. Keterlibatan orang tua sebagai wujud dari partisipasi terhadap pelaksanaan program yaitu :

a. Kegiatan bermain anak yaitu mendukung, mendorong dan berperan serta aktif Menunggu anak di luar kelas agar tidak mengganggu kegiatan belajar mengajar dan pendidik lebih leluasa dalam mengarahkan anak. Seperti yang diungkapkan Ibu.

b. Membiasakan anak masuk tepat waktu dan hadir 5 menit lebih awal sebelum kegiatan belajar berlangsung, tidak menyuapi anak sewaktu kegiatan belajar berlangsung.

c. Orang tua mengarahkan anak dan membereskan mainan terlebih yang tercecer di luar kelas.

d. Membayar iuran SPP secara rutin guna kelancaran untuk biaya operasional dan lainlain.

e. Memberikan dorongan kepada anak agar dapat belajar mandiri Ibu-ibu membiarkan anaknya untuk menyelesaikan tugasntya sendiri kok mbak. Para ibu-ibu hanya melihat dari luar kelas dan member semangat pada anaknya". Dari ungkapan di atas terbukti bahwa orang tua menyadari bahwa tidak membantu anaknya mengerjakan tugasnya meski hasilnya kurang sesuai adalah melatih anaknya untuk mandiri.

f. Orang tua memberikan stimulan pada anak di rumah, pendidik tidak hanya berlangsung di dalam kelas atau hanya di sekolah saja tetapi pendidikan yang lebih mendasar berada di lingkungan rumah atau keluarga. Sehingga 80 stimulasi dua arah lebih mampu mengoptimalkan perkembangan kecerdasan anak.

g. Mengikuti secara rutin pendidikan ibu yang dilaksanakan 2 kali dalam sebulan. Pendidikan ibu sangat dibutuhkan bagi stimulasi yang tepat untuk anak. Pendidikan ibu yang dilaksanakan oleh pihak lembaga menjadi landasan utama agar para oang tua mengetahui tanggung jawab dan haknya sebagai orang tua dalam menstimulasi dan mengoptimalkan perkembangan anak. 
h. Pemberian gizi bagi anak usia dini sangat penting. Karena pemberian gizi yang tidak tepat dan kurangnya asupan makan akan membuat anak kurang sehat dan kurang aktif sehingga anak kurang fokus terhadap pembelajaran.

i. Karya wisata bagi anak usia dini sangat diperlukan untuk menmabah wawasan anak tentang lingkungan sekitar. Selain itu karya wisata juga bisa menghibur anak-anak serta membentuk jiwa sosial yang tinggi. Hal tersebut karena dala karya wisata anak dihadapakan pada pola komunikasi atau interaksi sosial antar teman.

\section{Hasil Partisipasi}

Hasil dari partisipasi orang tua yaitu:

a. Kegiatan belajar mengajar di kelas maupun di luar kelas berjalan lancar

b. Pengelolaan biaya pendidikan berjalan positif karena orang tua membayar iuran sekolah secara rutin

c. Setiap tahun anak didik di lembaga PAUD meningkat. Hal ini seperti yang diungkapkan

d. Seluruh kegiatan yang diselenggarakan oleh lembaga berjalan lancar termasuk pendidikan ibu Keterlibatan orang tua dalam seluruh proses pelaksanaan program PAUD merupakan faktor pendukung utama bagi kelancaran program PAUD. Kepercayaan orang tua terhadap lembaga serta peran aktifnya bagi kelancaran suatu program akan mempunyai dampak yang baik bagi program PAUD itu sendiri. Hasil dari partisipasi orang tua yaitu pengelolaan keuangan lancar serta proses belajar mengajar di sekolah berjalan baik. Serta anak menjadi anak yang mandiri dan disiplin.

\section{E. PENUTUP}

Kesimpulan Berdasarkan hasil penelitian dan pembahasan mengenai partisipasi orang tua terhadap pelaksanaan program PAUD maka dapat ditarik kesimpulan sebagai berikut:

1. Partisipasi orang tua terhadap pelaksanaan program PAUD antara lain turut serta memberikan sumbangan fisik, turut serta memberikan sumbangan finansial berupa membayar iuran secara rutin, turut serta memberikan sumbangan materialberupa barang dalam bentuk alat permainan edukatif dan turut serta memberi sumbangan moral berupa saran, anjuran, nasehat, petuah dan amanah.

2. Sedang faktor penghambat yaitu:

a. Orang tua yang kurang mengarahkan anaknya untuk bisa mandiri;

b. Karakteristik orangtua yang berbeda-beda.

c. Upaya untuk mengatasi hambatan yaitu:

d. Pendidik dan pengelola memberikan pengertian pada orang tua untuk melatih kemandirian anak; 
e. Pendidik atau pengelola sebisa mungkin menjalin komunikasi yang baik dengan orangtua anak.

Saran Setelah peneliti melakukan penelitian terhadap partisipasi orang tua terhadap pelaksanaan program berikut beberapa saran yang dapat peneliti ajukan:

1. Partisipasi orang tua Pemahaman orang tua melalui kegiatan pendidikan ibu pengasuhan tepat di rumah. Perlu meningkatkan intensitas tatap muka dengan orang tua dan frekuensi pendidikan ibu lebih dioptimalkan. Keterlibatan orang tua untuk mengkondisikan dan mengarahkan anak untuk belajar tanpa didampingi di dalam kelas sangat mendukung kelancaran proses pembelajaran.

2. Faktor pendukung dan faktor penghambat Perlu menambah tenaga pendidik. Pentingnya peran pengelola dalam kegiatan pendidikan ibu. Selain itu peran serta masyarakat dalam program PAUD ini yang menyangkut dukungan dana, sosialisasi program PAUD dan pengarahan sangat dibutuhkan dalam mencapai keberhasilan program. 3. Upaya mengatasi hambatan Pendidik dan pengelola bekerja sama dengan orang tua dalam proses belajar mengajar anak. Sehingga dapat memaksimalkan peran masing-masing bagi tercapainya tujuan program.

\section{DAFTAR PUSTAKA}

Ahmad D.Marimba.1989. Pengantar Filsafat Pendidikan Islam. Bandung: AlMa'arif.

Ardiwinata, J. S. dan Mulyono, D. 2018. COMMUNITY EDUCATION IN THE DEVELOPMENT OF THE COMMUNITY. Empowerment, Vol. 7 (1). 25-35

Dadang Hawari.1977. Ilmu Kedokteran Jiwa dan Kesehatan Jiwa. Yogyakarta: Dana Bhakti Primayasa.

Damanhuri Rosadi.2002. Pedidikan Anak Usia Dini dalam Kerangka Otonomi Daerah, dalam Buletin PAUD. Jakarta: Direktorat Pendidikan Anak Usia Dini.

El Fiah Rifda. 2017. Bimbingan dan konseling anak usia dini. Depok: PT Rajagrafindo Persada

Depdiknas. Fasli Jalal.2004. Peran Pendidikan Non Formal dalam Pembangunan Manusia Indonesia yang Cerdas dan Bermutu. Yogyakarta: Universitas Negeri Yogyakarta. Gutama.2004.

Gutama.2004. Apa, Mengapa dan Siapa yang Bertanggungjawab terhadap Program Pendidikan Anak Usia Dini. Jakarta: Direktorat Pendidikan Anak Usia Dini.

Jasa Ungguh Muliawan.2009. Manajemen Play Group \& Taman KanakKanak.Yogyakarta: DIVA Press.

Khamim Zarkasyi Putro,M.Si.2005. Orangtua Sahabat Anak dan Remaja.Yogyakarta: Cerdas Pustaka.

Lexy J Moleong.2005. Metode Penelitian Kualitatif. Bandung: Remaja Rosdakarya. 
Mansur.2001. Diskursus Pendidikan Islam. Yogyakarta: Global Pustaka Utama.

Mansyur,MA.2005. Pendidikan Anak Usia Dini dalam Islam.Yogyakarta: Pustaka Pelajar. 